\title{
Omega-3 Fatty Acids Decrease the Proliferation of Rhabdomyosarcoma (RD) and Vero Cell Lines
}

\section{Muthana Ibrahim Maleek}

Department of Biology, College of Science, University of Wassit, Kut, Wassit, Iraq

\begin{abstract}
The effect of omega- 3 fatty acids, EPA and DHA, and combinations thereof on the viability of Rhabdomyosarcoma (RD) and Vero Cell Lineswas investigated. Various concentrations of these chemicals ranging from 0 to $80 \mu \mathrm{M}$ were tested using 96-well microtitration plates. Each well contained $0.2 \mathrm{ml}$ of treated cell suspension containing $10^{5}$ cells/ $\mathrm{ml}$. A micro-ELISA reader was used to measure the changes in cell viability. All tested individual concentrations and combinations reduced viability and this reduction was concentration dependent. Higher values of reduction was seen at $40 \mu \mathrm{M}$ followed by lesser inhibition at higher concentrations. Data were compared using Student T-test $(\mathrm{P}$ value of $\leq 0.05$ ). Mechanisms of effect of these drugs and their combinations are discussed. The present data could be used as a base line for further in vivo investigations and possible clinical considerations.
\end{abstract}

Keywords: Omega -3; EPA; DHA; Cancer cells; Transformed cell line; Cancer treatment; Apoptosis

\section{Introduction}

Knowledge about the importance of omega-3 polyunsaturated fatty acids (N-3 or n-3 PUFAs) in human health and diseases has been increasing constantly during recent years. Omega-3 fatty acids (popularly referred to as $\omega-3$ fatty acids or omega- 3 fatty acids) are essential unsaturatedfatty acids with a double bond $(\mathrm{C}=\mathrm{C})$ starting after the third carbon atom from the end of the carbon chain [1]. They are "essential" fatty acids because they are vital for normal metabolism and cannot be synthesized by the human body [2]. Nutritionally important n-3 fatty acids include $\alpha$-linolenic acid (ALA), eicosapentaenoic acid (EPA), and docosahexaenoic acid (DHA), all of which are polyunsaturated. More precisely, ALA cannot be synthesized by the human body at all, and the other $\mathrm{n}-3$ fatty acids can only be synthesized from ALA [3]. Many studies showed a positive role of $n-3$ fatty acids in the treatment of cardiovascular diseases [4], various mental illnesses [5], and cancer [6]. In cancer therapy, $n-3$ fatty acids are used to suppress cancer-associated cachexia and to improve the quality of life [7]. Other experimental studies on different cell cultures and animal models have determined the antitumor effect of $\mathrm{n}-3$ fatty acids both in vitro $[8,9]$ and in vivo $[10,11]$. An important aspect of the effects of $n-3$ fatty acids is that they cause little or no damage to normal cells [12]

Several studies reported possible anti-cancer effects of $n-3$ fatty acids, in particular, breast, colon, and prostate cancer [13-15]. Omega-3 fatty acids reduced prostate tumor growth, slowed histopathological progression, and increased survival in mice [16]. Nevertheless, neither long (DHA) chain nor short-chain (EPA) forms of $n-3$ fatty acids were consistently associated with breast cancer risk; but high levels of DHA, the most abundant $n-3$ fatty acids in erythrocyte membranes, were associated with a reduced risk of breast cancer [17].

A review of literature covering cohorts from many countries with a wide variety of demographics concluded that there was no link between $n-3$ fatty acids and cancer [18]. Similar findings failed to find clear effects of long and shorter chain $n-3$ fatty acids on total mortality, combined cardiovascular events and cancer [19]. This contradicts with other findings in that EPA can enhance the radiosensitivity of different human tumor cell lines [20].

A systematic review on Omega-3 fatty acids and cachexia found evidence that oral $n-3$ fatty acids supplements benefit cancer patients, improving appetite, weight, and quality of life [21]. A recent trial found that a supplement of EPA helped cancer patients retain muscle mass [22].

The present study aimed at testing the ability of omega-3 polyunsaturated fatty acid (EPA and DHA) to inhibit tumor cells in vitro.

\section{Materials and Methods}

\section{Cell lines}

All cell lines were kindly provided by Iraqi Center for Cancer and Medical Genetics Research.

\section{Rhabdomyosarcoma (RD) cell line}

This human cell line was derived from a biopsy specimen obtained from a pelvic rhabdomyosarcoma of a 7-year-old Caucasian girl [23]. It was used throughout this study and RPMI-1640 (Sigma, U.S.A) was used in maintaining the cells.

\section{Vero cell line}

This is a transformed cell line. It was initiated from the kidney of a normal adult African green monkey in 1962 by Y. Yasumura and Y. Kawakita at the Chiba University in Chiba, Japan [24]. Cells were maintained in Minimum Essential Medium (MEM) [Gibco, Scotland].

\section{Biochemical reagents}

DHA $[22: 6(n-3)]$ and EPA [20:5 (n-3)] were purchased from

*Corresponding author: Muthana Ibrahim Maleek, Department of Biology College of Science, University of Wassit, Kut, Wassit, Iraq, E-mail: muthana.ibrahem@yahoo.com

Received September 11, 2012, 2012; Accepted October 20, 2012; Published October 22, 2012

Citation: Maleek MI (2013) Omega-3 Fatty Acids Decrease the Proliferation of Rhabdomyosarcoma (RD) and Vero Cell Lines. J Cancer Sci Ther 5: 085-088. doi:10.4172/1948-5956.1000189

Copyright: (c) 2013 Maleek MI. This is an open-access article distributed unde the terms of the Creative Commons Attribution License, which permits unrestricted use, distribution, and reproduction in any medium, provided the original author and source are credited. 
Citation: Maleek MI (2013) Omega-3 Fatty Acids Decrease the Proliferation of Rhabdomyosarcoma (RD) and Vero Cell Lines. J Cancer Sci Ther 5: 085-088. doi:10.4172/1948-5956.1000189

Sigma-Aldrich, U.S.A. All other chemicals, solvents and reagents were supplied by BDH (UK) unless otherwise stated.

\section{Detection of the effect of DHA and EPA on cell lines}

The growth medium of confluent monolayer plates was decanted off and the cell sheet washed twice with PBS and trypsinized using trypsin-versene (Gibco, Canada) [25]. Cells were then re-suspended in fresh growth medium to give $10^{5}$ cells $/ \mathrm{ml}$. Aliquots of $0.2 \mathrm{ml}$ were transferred to each well of sterile 96-well microtitration plates. Plates were incubated until cells reaching exponential phase. Medium was removed and EPA and DHA at varying concentrations $(20,40,60$ and $80 \mu \mathrm{M}$ each) in serum free medium (SFM) plus DMSO $(1 \mu \mathrm{l} / \mathrm{ml})$ [26] were added. Similarly, combinations of these two chemicals of $10,20,30$ and $40 \mu \mathrm{M}$ each were employed. SFM was used to avoid any interference of the serum constituents, such as growth hormones and other components, on the actual effect of the drugs. All experiments were replicated five times. Twenty wells were used as control, i.e., cells treated with SFM plus DMSO only [25]. Plates were reincubated at $37^{\circ} \mathrm{C}$ for $24 \mathrm{hrs}$. Medium was replaced by $50 \mu \mathrm{l}$ of $0.01 \%$ crystal violet dye for 20 minutes, then washed gently and allowed to dry [25]. Optical density of each well was read by using a micro-ELISA reader (OrganonTeknika, Austria) at $492 \mathrm{~nm}$ transmitting wavelength [25,27]. The percentage of inhibition was calculated according to the following formula [28].

$$
\text { Inhibition }(\%)=\left[100-\frac{\text { opticaldensityof test wells }}{\text { optical density of control wells }}\right] \times 100
$$

Data were analyzed using Student's t-test against untreated cells. $P$ value of $\leq 0.05$ was considered statistically significant. Uncertainty (confidence limits) was represented in the figures by error bars.

\section{Results and Discussion}

Present findings indicate that Omega-3 fatty acids, EPA and DHA, can reduce viability of RD and Vero cell lines and such effects are concentration dependent, as given in figures 1 and 2, respectively. Generally, both drugs reduced cell viability in all tested concentrations. $\mathrm{EPA}$ at $20 \mu \mathrm{M}$ produced inhibitions of $44 \%$ and $40 \%$ for RD and Vero, respectively (Figure 1). Increasing the concentration of EPA increased viability inhibition. Highest values of inhibition of $62 \%$ for RD and $57 \%$ for Vero cell lines were seen at $40 \mu \mathrm{M}$, respectively. Further increase in concentration caused a continuous reduction in value of inhibition. At $60 \mu \mathrm{M} 47 \%$ for RD and $46 \%$ for Vero were achieved. While using $80 \mu \mathrm{M}$ of EPA produced the lower percentage of inhibition ( $40 \%$ for RD and $42 \%$ for Vero).

The picture is almost the same when different concentrations of DHA were tested. All tested concentrations produced profound reduction in viability of both $\mathrm{RD}$ and Vero cells (Figure 2). At $20 \mu \mathrm{M}$ inhibitions of $50 \%$ for RD and $46 \%$ for Vero were produced. The highest inhibition was seen at $40 \mu \mathrm{M}$, giving values of $74 \%$ and $69 \%$ for $\mathrm{RD}$ and Vero, respectively. Further increase in concentration $(60$ and $80 \mu \mathrm{M})$, produced continuous reductions in the inhibition of $56 \%$ for RD and $55 \%$ for Vero, and $44 \%$ for $\mathrm{RD}$ and $42 \%$ for Vero, respectively.

Study of the effects of combinations of EPA and HAD on the viability of the two cell lines is shown in (Figure 3). Inhibitions of $60 \%$ for $\mathrm{Rd}$ and $56 \%$ for Vero were seen when $10 \mu \mathrm{M}$ of each chemical were employed. Increasing the concentrations to $20 \mu \mathrm{M}$ of each of the two chemicals produced the highest percentage of inhibition to give values of inhibition of $80 \%$ and $74 \%$ inhibitions for RD and Vero, respectively.

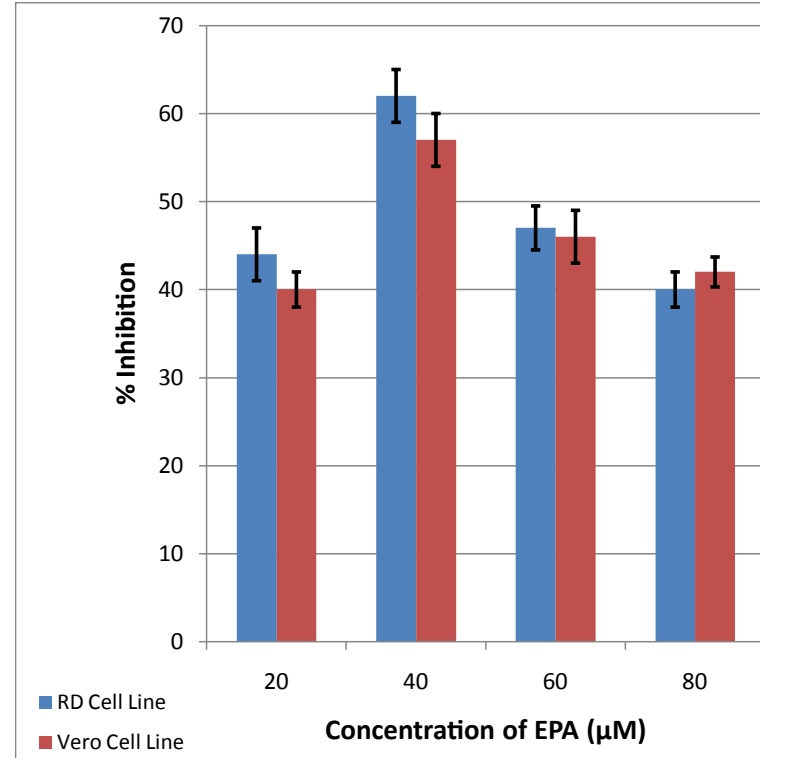

Figure 1: Effects of different concentrations of EPA on viability of RD and Vero cells $(P \leq 0.05)$. Data was compared, using Student's T-test, with those obtained from control samples where cell viability was studied without adding omega-3 fatty acids. Error bars represent confidence limits at $95 \%$ confidence level.

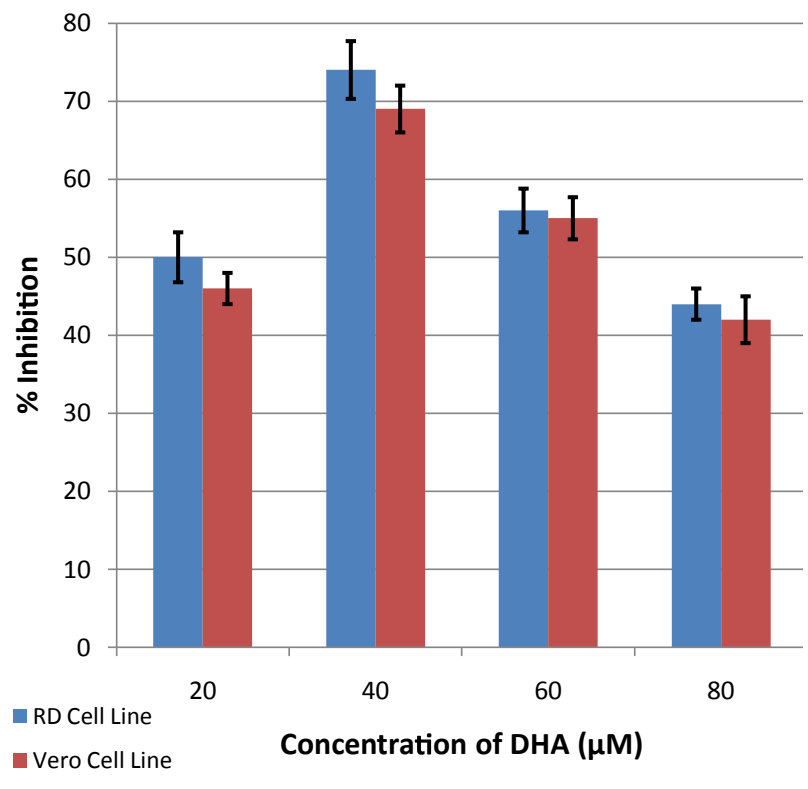

Figure 2: Effects of deferent concentrations of DHA on viability of RD and Vero cells $(P \leq 0.05)$. Data was compared, using Student's T-test, with those obtained from control samples where cell viability was studied without adding omega- 3 fatty acids. Error bars represent confidence limits at $95 \%$ confidence level.

Further increase in concentration produced a continuous reduction in inhibition. When $30 \mu \mathrm{M}$ of each of the agents were tested values of inhibition of $65 \%$ for RD and $62 \%$ for Vero was observed. Additional reduction was observed when $40 \mu \mathrm{M}$ of each agent giving viability inhibitions of $52 \%$ and $50 \%$ for $\mathrm{RD}$ and Vero, respectively.

Careful look at the combination data reveals that the two chemical 


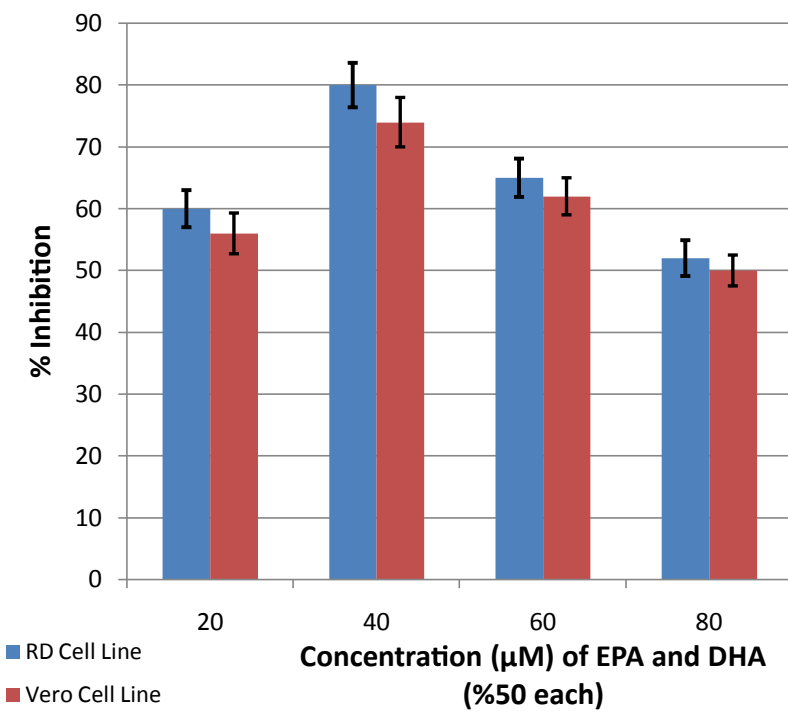

Figure 3: Effects of deferent combinations of EPA and DHA on viability of RD and Vero cells $(P \leq 0.05)$. The value of concentration is the sum of the concentrations (50\% each) of the two drugs. Data was compared, using Student's T-test, with those obtained from control samples where cell viability was studied without adding omega- 3 fatty acids. Error bars confidence limits at 95\% confidence level.

acted additively at the low concentrations, particularly at $40 \mu \mathrm{M}$ each (where the values of reduction are around $45 \%$ compared to that of the combined drugs at $20 \mu \mathrm{M}$ where each falls around $80 \%$. This may implicate that their modes of action are similar. Support to this notion comes from the fact that both drugs produce lesser values of viability reduction as higher concentrations and combinations thereof.

The reduction in the viability inhibition at higher concentrations may be explained on the bases that Omega-3 fatty acids are important structural components of cell membranes. When incorporated into phospholipids, they affect cell membrane properties such as fluidity, flexibility, permeability and the activity of membrane bound enzymes [29]. The cellular mechanisms studies of omega-3 with cancer cells suggest that it induces cell cycle arrest and apoptosis by activating protein phosphatases, leading to dephosphorylation of proteins. Protein phosphatases are also involved with the protein $\mathrm{Bcl} 2$, which regulates the release of cytochrome $c$ (a protein found in inner membranes of mitochondria), from mitochondria, and eventually, activation of the apoptotic enzyme caspase 3 [30]. Additionally, high omega-3 concentrations may reduce phosphorylation in various cell lines [3133], which supports the present findings in those higher concentrations reduce inhibition. However, this action is limited because the continuous increase of Omega-3 fatty acids concentration will inhibit all components that contain phosphate and lead to reduction in ATP formation. Such reduction in ATP will reduce the incorporation of Omega-3 fatty acids into cell membrane and eventually stop the distribution of Omega- 3 fatty acids through the cytoplasm. Accordingly, the effects of Omega-3 fatty acids will be reduced due to the fact that the incorporation of Omega-3 fatty acids into phospholipids could induce apoptosis [30-32] and that was clearly seen at 60 and $80 \mu \mathrm{M}$.

The present findings also show that DHA was a little more effective at increasing inhibition than EPA for cell lines under test. This may mainly be due to that part of the carbon chain of DHA has a higher degree of unsaturation than EPA. These double bounds can also serve as a substrate for peroxidation reactions resulting in reactive oxygen species and a pro-oxidant environment, which have been shown to induce apoptosis $[34,35]$.

Additional mechanistic implications is offered by the fact that omega-3 fatty acids influence inflammation through a variety of mechanisms; many of these are mediated by, or at least for the reduction associated with, changes in fatty acid composition of cell membranes. Changes in these compositions can modify membrane fluidity and cell signaling leading to altered gene expression [36]. Lipid signaling plays a critical role in the status of prostate cancer and many other human cancers [37-39]. The mitochondrial protein, cytochrome $c$, has a function in the intrinsic pathway of apoptosis and leads to the activation of caspase- 3 , which is a downstream enzyme in the apoptosis process and is involved in the execution phase of the death pathway [40]. As reported earlier [41-43] that DHA is rapidly taken up by cells and incorporated into membrane phospholipids and that both DHA and EPA activate protein phosphatases, leading to dephosphorylation of retinoblastoma protein (pRB). Accordingly, treating cells with DHA and EPA can possibly lead to the release of cytochrome $c$ and activation of caspase-3. These two compounds induce a cell signaling pathway for apoptosis that eventually leads to the death of cancer cells.

\section{References}

1. Nelson DL, Cox MM (2009) Lehninger Principles of Biochemistry. ( $5^{\text {th }}$ edn), WH Freeman and Company, New York.

2. Burdge $G$ (2004) Alpha-linolenic acid metabolism in men and women: nutritional and biological implications. Curr Opin Clin Nutr Metab Care 7: 137-144.

3. Burdge GC, Jones AE, Wootton SA (2002) Eicosapentaenoic and docosapentaenoic acids are the principal products of alpha-linolenic acid metabolism in young men*. Br J Nutr 88: 355-364.

4. Macchia A, Varini S, Grancelli H, Nul D, Laffaye N, et al. (2009) The rationale and design of the FORomegaARD Trial: A randomized, double-blind, placebo-controlled, independent study to test the efficacy of n-3 PUFA for the maintenance of normal sinus rhythm in patients with previous atrial fibrillation. Am Heart J 157: 423-427.

5. Riediger ND, Othman RA, Suh M, Moghadasian MH (2009) A systemic review of the roles of $n-3$ fatty acids in health and disease. J Am Diet Assoc 109 668-679.

6. Allred CD, Talbert DR, Southard RC, Wang X, Kilgore MW (2008) PPARgamma1 as a molecular target of eicosapentaenoic acid in human colon cancer (HT-29) cells. J Nutr 138: 250-256.

7. Argiles JM (2005) Cancer-associated malnutrition. Eur J Oncol Nurs 2 S39-S50.

8. Das UN (2007) Gamma-linolenic acid therapy of human gliomas-a review of in vitro, in vivo, and clinical studies. Med Sci Monit 13: 119-131.

9. Heimli H, Finstad HS, Drevon CA (2001) Necrosis and apoptosis in lymphoma cell lines exposed to eicosapentaenoic acid and antioxidants. Lipids 36: 613621

10. Bathen TF, Holmgren K, Lundemo AG, Hjelstuen MH, Krokan HE, et al (2008) Omega-3 fatty acids suppress growth of SW620 human colon cancer xenografts in nude mice. Anticancer Res 28: 3717-3723.

11. Black HS, Rhodes LE (2006) The potential of omega-3 fatty acids in the prevention of non-melanoma skin cancer. Cancer Detect Prev 30: 224-232.

12. Igarashi M, Miyazawa T (2000) Do conjugated eicosapentaenoic acid and conjugated docosahexaenoic acid induce apoptosis via lipid peroxidation in cultured human tumor cells? Biochem Biophys Res Commun 270: 649-656.

13. Augustsson K, Michaud DS, Rimm EB, Leitzmann MF, Stampfer MJ, et al (2003) A prospective study of intake of fish and marine fatty acids and prostate cancer. Cancer Epidemiol Biomarkers Prev 12: 64-67. 
Citation: Maleek MI (2013) Omega-3 Fatty Acids Decrease the Proliferation of Rhabdomyosarcoma (RD) and Vero Cell Lines. J Cancer Sci Ther 5: 085-088. doi:10.4172/1948-5956.1000189

14. De Deckere EA (1999) Possible beneficial effect of fish and fish n-3 polyunsaturated fatty acids in breast and colorectal cancer. Eur J Cancer Prev 8: 213-221.

15. Caygill CP, Hill MJ (1995) Fish, n-3 fatty acids and human colorectal and breast cancer mortality. Eur J Cancer Prev 4: 329-332.

16. Berquin IM, Min Y, Wu R, Wu J, Perry D, et al. (2007) Modulation of prostate cancer genetic risk by omega-3 and omega-6 fatty acids. J Clin Invest 117 : 1866-1875.

17. Pala V, Krogh V, Muti P, Chajès V, Riboli E, et al. (2001) Erythrocyte membrane fatty acids and subsequent breast cancer: a prospective Italian study. J Natl Cancer Inst 93: 1088-1095.

18. MacLean CH, Newberry SJ, Mojica WA, Khanna P, Issa AM, et al. (2006) Effects of omega-3 fatty acids on cancer risk: a systematic review. JAMA 295: 403-415

19. Hooper L, Thompson RL, Harrison RA, Summerbell CD, Ness AR, et al. (2006) Risks and benefits of omega 3 fats for mortality, cardiovascular disease, and cancer: systematic review. Brit Med J 332: 752-760.

20. Manda K, Kriesen S, Hildebrandt G, Fietkau R, Klautke G (2011) Omega-3 fatty acid supplementation in cancer therapy : does eicosapentanoic acid influence the radiosensitivity of tumor cells? Strahlenther Onkol 187: 127-134.

21. Colomer R, Moreno-Nogueira JM, García-Luna PP, García-Peris P, García-deLorenzo A, et al. (2007) N-3 fatty acids, cancer and cachexia: a systematic review of the literature. $\mathrm{Br} \mathrm{J}$ Nutr 97: 823-831.

22. Ryan AM, Reynolds JV, Healy L, Byrne M, Moore J, et al. (2009) Enteral nutrition enriched with eicosapentaenoic acid (EPA) preserves lean body mass following esophageal cancer surgery: results of a double-blinded randomized controlled trial. Ann Surg 249: 355-363.

23. McAllister RM, Melnyk J, Finkelstein JZ, Adams EC Jr, Gardner MB (1969) Cultivation in vitro of cells derived from a human rhabdomyosarcoma. Cancer 24: $520-526$.

24. Bianchi NO, Ayres J (1971) Heterochromatin location on chromosomes of normal and transformed cells from African green monkey (Cercopithecus aethiops). DNA denaturation-renaturation method. Exp Cell Res 68: 253-258.

25. Freshney RI (1994) Culture of animal cells. ( $3^{\text {rd }}$ edn), Wiley-Liss, USA.

26. Reiners JJ Jr, Clift RE (1999) Aryl hydrocarbon receptor regulation of ceramideinduced apoptosis in murine hepatoma $1 \mathrm{c} 1 \mathrm{c} 7$ cells. A function independent of aryl hydrocarbon receptor nuclear translocator. J Biol Chem 274: 2502-2510.

27. Mahony DE, Gilliatt E, Dawson S, Stockdale E, Lee SH (1989) Vero cell assay for rapid detection of Clostridium perfringens enterotoxin. Appl Environ Microbiol 55: 2141-2143.

28. Chiang LC, Chiang W, Chang MY, Lin CC (2003) In vitro cytotoxic, antiviral and immunomodulatory effects of Plantago major and Plantago asiatica. Am J Chin Med 31: 225-234.
29. Stillwell W, Wassall RS (2003) Docosahexaenoic acid: membrane properties of a unique fatty acid. Chem Phys Lipids 26: 1-27.

30. Siddiqui RA, Shaikh SR, Sech LA, Yount HR, Stillwell W, et al. (2004) Omega 3-fatty acids: health benefits and cellular mechanisms of action. Mini Rev Med Chem 4: 859-871.

31. Datta SR, Katsov A, Hu L, Petros A, Fesik SW, et al. (2000) 14-3-3 proteins and survival kinases cooperate to inactivate $\mathrm{BAD}$ by $\mathrm{BH} 3$ domain phosphorylation. Mol Cell 6: 41-51.

32. Sastry KS, Smith AJ, Karpova Y, Datta SR, Kulik G (2006) Diverse antiapoptotic signaling pathways activated by vasoactive intestinal polypeptide, epidermal growth factor, and phosphatidylinositol 3-kinase in prostate cancer cells converge on BAD. J Biol Chem 281: 20891-20901.

33. She QB, Solit DB, Ye Q, O'Reilly KE, Lobo J, et al. (2005) The BAD protein integrates survival signaling by EGFR/MAPK and PI3K/Akt kinase pathways in PTEN-deficient tumor cells. Cancer Cell 8: 287-297.

34. VaculovaA, HofmanovaJ,AnderaL,KozubikA(2005)TRAILanddocosahexaenoic acid cooperate to induce HT-29 colon cancer cell death. Cancer Lett 229: 4348 .

35. Simon HU, Haj-Yehia A, Levi-Schaffer F (2000) Role of reactive oxygen species (ROS) in apoptosis induction. Apoptosis 5: 415-418.

36. Calder PC (2010) Omega-3 fatty acids and inflammatory processes. Nutrients 2: $355-374$.

37. Suzuki H, Freije D, Nusskern DR, Okami K, Cairns P, et al. (1998) Interfocal heterogeneity of PTEN/MMAC1 gene alterations in multiple metastatic prostate cancer tissues. Cancer Res 58: 204-209.

38. Vlietstra RJ, vanAlewijkDC, Hermans KG, van Steenbrugge GJ, Trapman J(1998) Frequent inactivation of PTEN in prostate cancer cell lines and xenografts. Cancer Res 58: 2720-2723.

39. Maleek MI (2010) Cytotoxic and inhibitory activity of ceramide on cancer cel lines. J Biomed Sci Eng 3: 892-899.

40. StennickeHR, Salvesen GS (1998)Properties of the caspases. Biochim BiophysActa 1387: 17-31.

41. Williams EE, Jenski LJ, Stillwell W (1998) Docosahexaenoic acid (DHA) alters the structure and composition of membranous vesicles exfoliated from the surface of a murine leukemia cell line. Biochim Biophys Acta 1371: 351-362.

42. Scherer JM, Stillwell W, Jenski LJ (1997) Spleen cell survival and proliferationare differentially altered by docosahexaenoic acid. Cell Immunol 180: 153-161.

43. Zerouga M, StillwellW, Stone J, PownerA, JenskiLJ (1996)Phospholipid classasa determinant in docosahexaenoic acid's effect on tumor cell viability. Anticancer Res 16: 2863-2868. 